\title{
Pengembangan Media Virtual Tour Pada Gedung Teaching Factory Politeknik Negeri Batam
}

\author{
Ika Juniar Kristiani Hutapea*, Riwinoto** \\ Program Studi Teknik Multimedia dan Jaringan, Jurusan Teknik Informatika \\ Politeknik Negeri Batam, Batam, Indonesia \\ Email: *ikajuniarkristiani93@gmail.com, **riwi@polibatam.ac.id
}

\begin{abstract}
Article Info $\quad$ ABSTRACT
Article history:

Received Oct 17 th, 2020

Revised Nov 4th, 2020

Accepted Dec 6th, 2020

Keyword:
Virtual Reality
Virtual Tour
Gedung Teaching Factory
Politeknik Negeri Batam
Luther-Sutopo

Keyword:

Gedung Teaching Factory

Luther-Sutopo

Virtual reality is currently growing rapidly; a variety of industrial products have emerged that are integrated with the virtual world in various sectors. Since 2018, the virtual laboratory of the Batam State Polytechnic has developed learning products that support virtual reality technology. These learning products are in the form of games and learning simulations. It is expected that through the learning products produced, the learning activities will be more targeted and the effectiveness of lectures will increase.

Virtual touring is one of the benefits of virtual reality technology. In the tourism sector, many virtual touring media have been developed that are useful in the introduction and promotion of local tourism place. Adopting the advantages and benefits of virtual tours in the tourism sector, the education sector has also developed many virtual tour media that are useful in introducing related educational institutions or institutions. These benefits will be developed by Batam State Polytechnic to introduce one of the Lecture Buildings, the Teaching Factory. This virtual tour media will be addressed to Batam State Polytechnic guests who come to visit to introduce virtual laboratory facilities and students who need information on the location and condition of the Batam State Polytechnic Teaching Factory Building.
\end{abstract}

Copyright (c) 2020 Institute of Advanced Engineering and Science. All rights reserved.

\section{PENDAHULUAN}

Gedung Teaching Factory adalah salah satu gedung pembelajaran yang dimiliki oleh Politeknik Negeri Batam saat ini. Terdiri dari sembilan lantai dengan dua lantai yang masih dalam tahap pembangunan. Gedung Teaching Factory menjadi tempat proses perkuliahan untuk mahasiswa jurusan Teknik Elektro dan Teknik Informatika.

Jurusan Teknik Elektro menggunakan lantai satu dan lantai dua sebagai tempat pelaksanakannya kegiatan perkuliahan. Terdiri dari ruang belajar dan laboratorium pembuatan produk-produk elektro seperti $P C I$, sedangkan Jurusan Teknik Informatika yang terdiri dari Program Studi Multimedia dan Jaringan menggunakan lantai tiga dan empat, Program Studi Animasi menggunakan lantai empat dan Program Studi Teknik Geomatika menggunakan lantai lima untuk menunjang segala proses kegiatan perkuliahan dan praktikum. Lantai enam dan lantai tujuh yang masih dalam tahap pembangunan diperkirakan akan selesai dalam satu sampai dua tahun kedepan.

Virtual reality merupakan teknologi yang memungkinkan pengguna melakukan simulasi terhadap suatu objek 3D dengan menggunakan komputer [1]. Objek 3D yang dipakai dalam dunia virtual mampu membangkitkan suasana seolaholah pengguna mengerjakan atau melakukan sesuatu hal secara nyata. Produk yang dihasilkan dari teknologi virtual reality biasanya berupa simulasi kegiatan seperti simulasi perang, simulasi penerbangan pesawat dan sebagainya.

Virtual Tour merupakan salah satu manfaat yang dapat diperoleh dengan pengembangan virtual reality. Menggambarkan suasana dan kondisi yang sesuai dengan bentuk nyata suatu gedung, lokasi atau wilayah. Pengguna media virtual tour dapat mengenal dan mengetahui suatu lingkungan tanpa perlu datang ke lokasi bersangkutan secara langsung. Efektifitas waktu 
dan tenaga tentunya menjadi keuntungan dari pemanfaatan media virtual tour.

Pada tahun 2018, Politeknik Negeri Batam telah memiliki fasilitas laboratorium virtual reality yang terletak pada Gedung Teaching Factory lantai empat. Laboratorium ini dapat diakses oleh mahasiswa dan dosen untuk pengembangan riset kampus. Produk virtual reality yang berupa game dan simulasi telah banyak dihasilkan oleh mahasiwa Politeknik Negeri Batam.

Melebarkan sayap untuk pemanfaatan teknologi virtual reality di lingkungan kampus Politeknik Negeri Batam yang saat ini hanya berupa simulasi pembelajaran dan game hasil tugas besar atau proyek internal mahasiswa, penulis akan mengembangkan media virtual tour. Salah satu produk teknologi virtual tour yang akan dikembangkan oleh penulis adalah Gedung Teaching Factory. Harapan penulis media virtual tour ini nantinya akan berguna dalam memperkenalkan lokasi, kondisi dan struktur Gedung Teaching Factory secara real-timekepada setiap tamu Politeknik Negeri Batam yang datang berkunjung serta mahasiswa yang menggunakan fasilitas virtual reality laboratory Politeknik Negeri Batam.

\section{LANDASAN TEORI}

\section{A. Tinjauan Pustaka}

"Aplikasi 3D Virtual Reality Sebagai Media Pengenalan Kampus Politeknik Negeri Indramayu Berbasis Mobile" oleh Firman Setiawan Riyadi, A. Sumarudin dan Munengsih Sari Bunga (2017) adalah jurnal yang berisi pengembangan aplikasi 3D virtual reality di Kampus Politeknik Negeri Indramayu sebagai media promosi Kampus. Aplikasi 3D virtual reality yang dihasilkan berbasis mobile [2].

Dengan topik dan masalah yang hampir serupa, Tugas Akhir "Virtual Tour Sebagai Media Promosi Pariwisata Bahari Kota Batam" oleh Ichsan Syah Putra (2018) memuat metode Luther Sutopo dalam mengembangkan produk virtual tour Pariwisata Bahari Kota Batam [3].

"Teknologi Virtual Reality Untuk Media Informasi Kampus" oleh Herman Thuan To Saurik, Devi Dwi Purwanto dan Jeremiah Irawan Hadikusuma Herman, Devi \& Jeremiah (2018) juga menghasikan produk virtual reality berbasis mobile dalam membangun produk virtual berupa gedung, ruangan dan fasilitas yang berdasarkan aspek rekayasa perangkat lunak [4].

Dari ketiga rujukan diatas, maka akan dibuat sebuah produk virtual reality yang menerapkan manfaat virtual tour dengan menggunakan Metode Luther Sutopo (concept, design, collecting content material, assembly, testing dan distribution).

\section{B. Virtual Reality}

Virtual Reality adalah teknologi yang memungkinkan pengguna untuk melakukan simulasi terhadap suatu objek nyata tiga dimensi (3D) menggunakan komputer sehingga pengguna merasakan sensasi seolaholah terlibat secara fisik [5]. Virtual reality juga membuat pengguna dapat berinteraksi dengan suatu lingkungan yang disimulasikan oleh komputer dengan meniru lingkungan realworld dan melibatkan semua indera manusia. Perkembangan dunia virtual yang semakin hari semakin matang tampak jelas dengan munculnya berbagai aplikasi berbasis $v r$ seperti simulasi pelatihan, konser virtual, permainan dan lain sebagainya [6].

\section{Virtual Tour}

Virtual tour merupakan sebuah simulasi dari sebuah lokasi yang terdiri dari rentetan gambar atau objek 3D. Objek dan rentetan gambar tersebut akan digabungkan (stitch) untuk menghasilkan sebuah lokasi yang 'benarbenar sama' pada dunia virtual. Virtual tour juga digunakan untuk memberi pengalaman 'pernah berada' di suatu tempat hanya dengan melihat layar monitor komputer. Penyajian virtual tour dapat dilakukan dengan cara memanfaatkan gambar ataupun video, selain itu dapat digunakan model 3 dimensi [7].

\section{Gedung TF Politeknik Negeri Batam}

Politeknik Negeri Batam memilki empat gedung perkuliahan utama. Satu dari empat gedung tersebut adalah Teaching Factory. Gedung Teaching Factory menjadi tempat kegiatan perkuliahan bagi mahasiswa Teknik Elektonika dan Teknik Informatika. Pada gedung ini juga memproduksi produk-produk elektonika seperti IC Packaging dan $P C B$ hingga 6 layer [8].

Gedung Teaching Factory memiliki sembilan latai yang dimulai dari lantai basement hingga lantai tujuh. Pelaksanaan kegiatan perkuliahan berada pada lantai dasar hingga lantai dua bagi mahasiswa jurusan Teknik Elektronika, sedangkan pelaksanaan kegiatan perkuliahan bagi mahasiswa jurusan Teknik Informatika berada pada tiga, empat dan lima. Struktur ruangan pada Gedung Teaching Factory terdiri dari ruang clean room, ruang soldering, toilet, mushola, ruang kelas, ruang praktikum, laboratorium dan ruang dosen. Denah setiap lantai dapat dilihat pada gambar dibawah ini

\section{E. HTC VIVE}

Sebuah perangkat hardware virtual reality yang diproduksi oleh dua perusahaan HTC dan Valve. Perangkat tersebut menggunakan Room Scale Technology dimana pengguna dapat bergerak di ruang sekitarnya 
dan menggunakan motion tracked controller untuk berinteraksi dalam dunia virtual yang dijalankan.

HTC VIVE terdiri dari 3 bagian yang terhubung melalui connector perangkat tersebut yaitu Headset, VR Controller dan Base Station.

\section{F. Unity}

Unity 3D merupakan salah satu software untuk membuat konten interaktif seperti visual arsitektur dan real-time 3D animasi. Unity 3D tidak hanya mencakup game engine, tetapi juga merangkap sebagai editor. Kelebihan dari unity 3D yaitu multi platform. Selain itu, unity 3D mendukung bahasa pemrograman $\mathrm{C \#}$ dan $\mathrm{C}++$ sebagai bahasa pemrograman alteranatif. Unity dapat dioperasikan pada platform Windows dan Mac Os dan dapat menghasilkan Game untuk Windows, Mac, Linux, Wii, IPad, IPhone, Google Android dan juga browser [9].

\section{G. Blender}

Blender merupakan salah satu software modeling, rendering dan animasi 3D populer saat ini selain kompetitornya Autodesk Maya dan 3D Max. Diantara aplikasi 3D modelling yang lain, blender adalah perangkat lunak gratis yang memungkinkan penambahan script atau unsur-unsur baru, meningkatkan kapasitas dan memperbaiki program untuk bekerja sesuai dengan keinginan programmer [10].

Keunggulan dari aplikasi blender yaitu ukuran aplikasinya yang lebih ringan dibandingkan aplikasi modelling 3D yang lain, open source dan multi platform. Selain berfungsi untuk modeling dan animasi 3D, blender juga dapat digunakan sebagai aplikasi editing video bahkan gambar. Beberapa kemampuan dari blender adalah: mendukung keanekaragaman dari bentuk geometriprimitif, termasuk polygon yang tak beraturan, fast subdivision, surfaced modelling, kurva Bezier, metaballs, dan lain-lain [11].

\section{H. Bahasa Programming C\#}

C\# atau disebut juga $C$ Sharp adalah bahasa pemograman berorientasi objek yang digunakan untuk tujuan umum yang dikembangkan oleh Microsoft. Bahasa pemograman ini mengandung konsep seperti inheritance, class, polymorphism, dan encapsulation. C\# bergantung pada framework bernama .NET Framework untuk mengcompile seluruh kodenya

\section{Metode Luther-Sutopo}

Metode Luther Sutopo atau umumnya dikenal dengan Multimedia Development Life Cycle (MDLC) adalah sebuah metode pengembangan produk multimedia yang terdiri dari 6 tahapan yaitu, concept, design, material collecting, assembly, testing dan distribution. Luther juga menggunakan istilah "authoring" untuk mendefinisikan pengembangan perangkat lunak multimedia [12].

Menurut Luther dalam Binanto (2015) pengembangan produk multimedia menggunakan metode ini tidak harus berurutan setiap tahapannya, namun walaupun begitu tetap harus dimulai dengan tahapan perencanaan (concept dan design) terlebih dahulu [13].

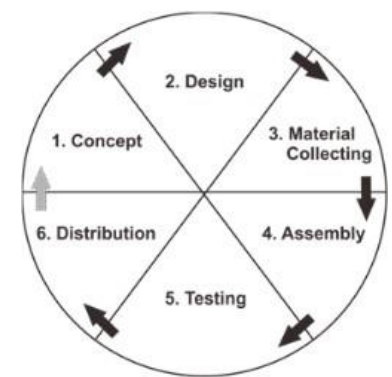

Gambar 1. Metode Luther Sutopo

Tahap MDLC sebagai berikut:

1. Concept

Tahap awal yang memiliki tujuan untuk menentukan konsep, identifikasi pengguna, manfaat, tujuan dan spesifikasi umum aplikasi.

2. Design

Tahap perancangan user interface dan penentuan secara rinci material/bahan yang dibutuhkan untuk merancang aplikasi.

3. Material Collecting

Tahap pengumpulan bahan yang sesuai dengan kebutuhan produk yang akan dibangun. Bahan-bahan yang dibutuhkan dapat berupa gambar, foto, video, audio dan lain-lain yang dapat diperoleh dari berbagai sumber.

\section{Assembly}

Tahap assembly adalah tahap pembuatan asset dan implementasi pembuatan produk sehingga aplikasi dapat digunakan.

\section{Testing}

Tahap pengujian dilakukan setelah produk selesai dibangun untuk memastikan bahwa produk dapat berjalan dengan baik ataupun dan penggunaannya sesuai dengan tujuan dan hasil yang diharapkan. Tahap ini terdiri dari dua tahapan yaitu alpha test dan beta test.

\section{Distribution}

Pada tahap ini, produk yang telah berhasil diuji disimpan pada suatu media penyimpanan seperti flashdisk, DVD-RW ataupun internet agar selanjutnya dapat digunakan dan diakses kembali untuk tujuan pengembangan sistem selanjutnya. 


\section{METODE PENELITIAN}

Penelitian diawali dengan menentukan hal-hal umum yang mendasari pembuatan produk virtual tour. Hal-hal umum tersebut terdiri dari konsep produk, maanfaat produk, identifikasi sistem pembangun produk, target pengguna dan tujuan penelitian. Hal-hal tersebut haruslah dijelaskan secara jelas dan rinci agar produk virtual tour yang nantinya dihasilkan dapat dipakai sebagaimana mestinya dan berguna untuk tujuan jangka panjang.

Kemudian penelitian menuju tahap perancangan produk dengan melakukan pembuatan sketsa tampilan interface dari produk virtual tour salah satu gedung perkuliahan Politeknik Negeri Batam yaitu Gedung Teaching Factory. Gedung Teaching Factory yang digunakan memiliki enam lantai yang terdiri dari ruang perkuliahan, ruang dosen, laboratorium, toilet, pantry dan mushola. Selanjutnya dilakukan observasi gedung dan pengambilan foto. Dari hasil foto kemudian dilakukan pemodelan 3D dengan menggunakan software Blender untuk menghasilkan file FBX.

Pada tahap selanjutnya file FBX diimport kedalam game engine Unity untuk menghasilkan object yang akan diaplikasikan kedalam media VR menggunakan plugin SteamVR. Pada beberapa object diberikan file berekstensi .cs agar object tersebut dapat melakukan fungsi tertentu, seperti pintu yang terbuka, menampilkan informasi ruangan, dan berpindah tempat dalam gedung. Bahasa pemograman yang digunakan adalah c\# (C sharp). Implementasi yang dilakukan pada object 3D dan file .cs sebagai kebutuhan informasi gedung dan ruang kemudian menghasilkan aplikasi VR yang disimpan pada kmputer labooratorium Virtual Reality Pliteknik Negeri Batam.

Pengujian pada produk virtual tour gedung Teaching Factory yang dibuat bertujuan untuk mengetahui apakah produk virtual tour sudah berjalan dengan baik secara fungsional dan tujuan dari penelitian terpenuhi atau tidak. Ujicoba dilakukan dengan menggunakan perangkat HTC VIVE milik laboratorium Virtual Reality Politeknik Negeri Batam. Lalu disebar kuesioner yang digunakan sebagai media penilaian terhadap produk virtual tour.

\section{HASIL DAN PEMBAHASAN}

\section{A. Pengumpulan Bahan}

Dalam tahap ini terdapat pengumpulan bahan yang berupa gambar denah gedung Teaching Factry Politeknik Negeri Batam, gambar bangunan gedung-gedung dan lingkungan tersebut untuk kemudian digunakan sebagai referensi pada proses pembuatan $3 D$ Modelling.

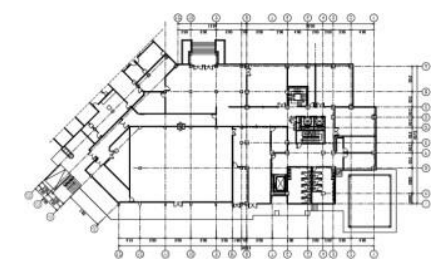

Gambar 2. Denah Gedung Teaching Factory Pliteknik Negeri Batam

\section{B. Modelling Objek Gedung}

Pemodelan objek 3D ini dibuat menggunakan aplikasi Blender dan didasarkan pada referensi denah dan foto yang telah dikumpulkan sebelumnya pada tahap material collecting sebagai acuan.

\section{Modelling object}

Tahap pertama yang dilakukan adalah membuat objek 3D yang dibutuhkan oleh produk virtual tour gedung Teaching Factory Politeknik Negeri Batam. Selain objek gedung, tahap ini juga memodelkan properti beserta aset gedung yang dibutuhkan. Pemodelan objek 3D ini dibuat menggunakan aplikasi Blender dan didasarkan pada referensi denah dan foto yang telah dikumpulkan sebelumnya pada tahap material collecting sebagai acuan. Objekobjek 3D yang dihasilkan dibentuk sedemikian rupa sehingga memiliki kemiripan dengan objek sesungguhnya.

2. Texturing object

Tahap texturing bertujuan untuk memberi tekstur pada objek 3D yang telah selesai dibuat. Tahap ini juga menentukan karakteristik pada material yang membangun objek seperti warna dinding, lantai, atap dan lain-lain. Tekstur yang diberikan dibuat semirip mungkin dengan kondisi gedung Teaching Factory yang sesungguhnya.

3. Export object

Setelah tahap modelling dan texturing selesai dilakukan maka selanjutnya adalah exporting object ke dalam file berekstensi .FBX. File jenis ini dapat dimanipulasi lebih lanjut seperti penggabungan dan penyusunan objek. 

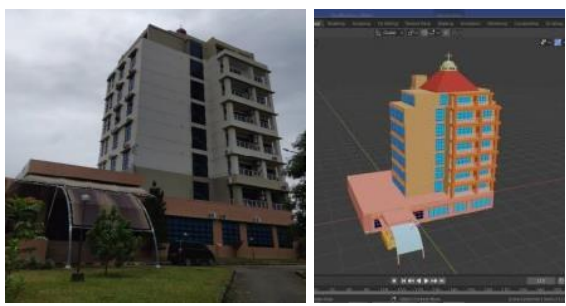

Gambar 3. Tahap modeling gedung Teaching Factory Politeknik Negeri Batam

\section{Penggabungan dan Penyusunan Objek}

Pada tahap ini dilakukan importing asset kedalam aplikasi Unity. Objek 3D gedung

Teaching Factory disusun dan dibentuk sedemikian rupa sehingga memiliki bentuk yang menyerupai kondisi sesungguhnya.

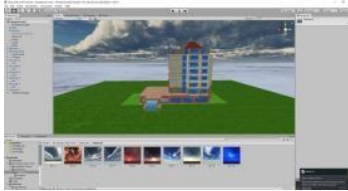

Gambar 4. Tahap penyusunan objek pada Unity

\section{Penambahan Script}

Tahap ini menambahkan script pada beberapa objek didalam produk virtual tour sehingga objek tersebut dapat melakukan sebuah fungsi yang dibutuhkan bagi produk virtual tour gedung Teaching Factory Politeknik Negeri Batam.

\section{E. Implementasi Tampilan Aplikasi Virtual Tour}

1. Tampilan Menu Utama

Tampilan awal saat pertama kali produk dijalankan pada sistem.

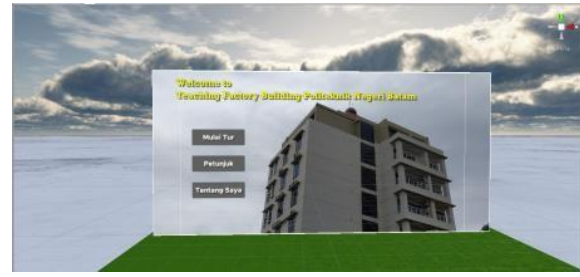

Gambar 5. Tampilan menu awal

2. Tampilan Menu Mulai Tour

Menu pertama pada halaman menu utama. Saat menu ini dipilih pengguna dapat masuk kedalam gedung secara virtual dan memulai untuk berinteraksi dengan objek.

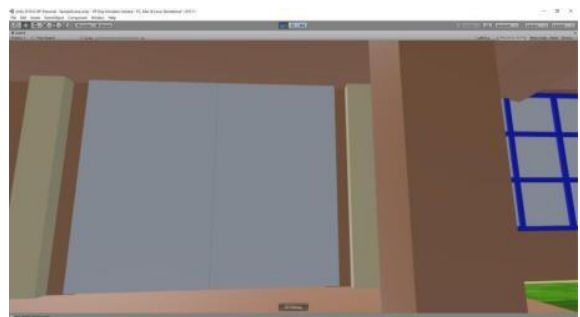

Gambar 6. Tampilan menu Mulai Tour

3. Tampilan Menu Petunjuk

Menu kedua yang menampilkan penggunaan pemakaian perangkat vr untuk menjalankan produk virtual tour.

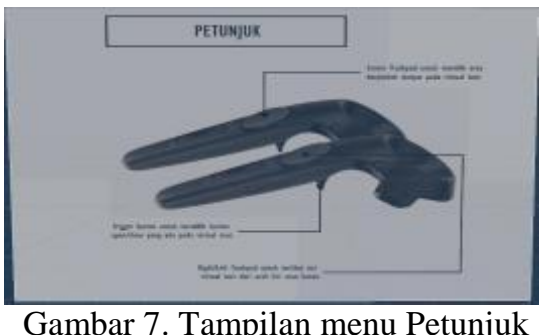

4. Tampilan Menu Tentang Saya Menu terakhir pada produk virtual tour yang menampilkan keterangan dari produk virtual tour.

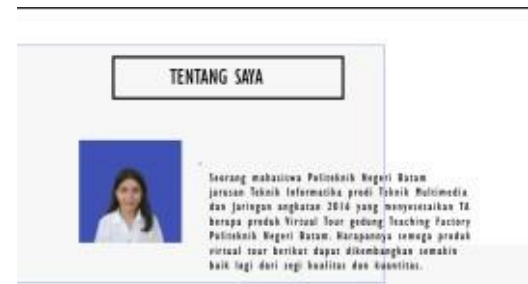

Gambar 8. Tampilan Menu Tentang Saya

\section{F. Pengujian Alpha}

Pengujian alpha menggunakan metode pengujian blackbox. Blackbox testing adalah pengujian yang dilakukan untuk mengetahui apakah produk virtual tour yang dibangun dapat berjalan dengan baik dari segi fungsionalitas [14]. Berikut ini adalah pengujian blackbox yang dilakukan pada produk virtual tour gedung Teaching Factory Politeknik Negeri Batam. 


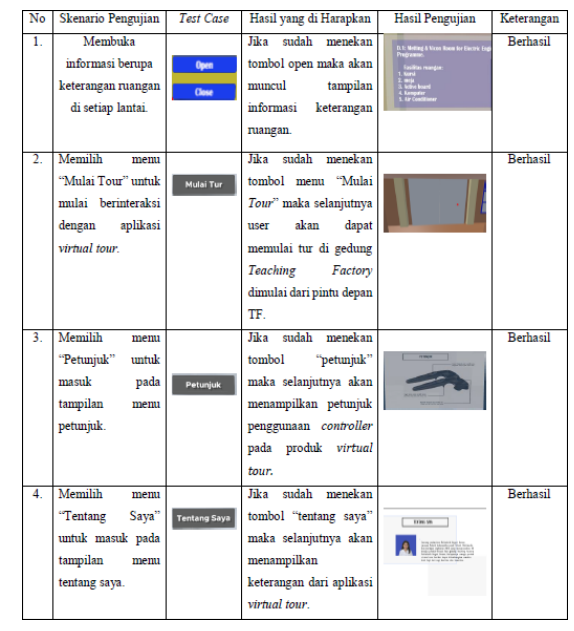

Gambar 9. Hasil pengujian Blackbox

\section{G. Pengujian Beta}

Pengujian beta adalah pengujian yang dilakukan dengan tujuan untuk mengetahui kualitas produk yang dibangun, pengujian ini merupakan pengujian yang bersifat langsung di lingkungan yang sebenarnya [15]. Pengguna sebagai responden melakukan penilaian secara langsung terhadap produk virtual tour gedung Teaching Factory Politeknik Negeri Batam dengan menggunakan media kuesioner. Dari hasil kuesiner yang dikumpulkan maka dapat ditarik kesimpulan apakah aplikasi yang dibangun sesuai dengan tujuan atau tidak.

Proses penilaian produk virtual tour gedung Teaching Factory Politeknik Negeri Batam oleh responden berdasarkan target pengguna dalam hal ini adalah dosen, dan mahasiswa Politeknik Negeri Batam dilakukan di dalam ruangan Laboratorium Virtual Reality Politeknik Negeri Batam. Produk virtual tour akan dinilai oleh 30 orang responden sebagai sampel dengan memastikan terlebih dahulu bahwa para responden memiliki pengalaman mengunjungi gedung Teaching Factory Politeknik Negeri Batam sebelumnya.

Setelah semua kuesioner didapatkan maka selanjutnya dilakukan penghitungan dengan menggunakan skala likert dimana data dianalisis dengan menghitung rata-rata jawaban berdasarkan skoring setiap jawaban dari responden lalu kemudian dijumlahkan. Adapun bobot jawaban pada kuesioner adalah sebagai berikut:
Tabel 1. Bobot Setiap Jawaban

\begin{tabular}{|c|c|}
\hline Kategori Jawaban & Skor \\
\hline Sangat Setuju & 1 \\
\hline Setuju & 2 \\
\hline Netral & 3 \\
\hline Tidak Setuju & 2 \\
\hline $\begin{array}{c}\text { Sangat Tidak } \\
\text { Setuju }\end{array}$ & 1 \\
\hline
\end{tabular}

Untuk mencari presentase dari masingmasing jawaban kuesioner digunakan rumus skala likert sebagai berikut:

$$
P=\frac{\square}{\square \square \square \square \square \square \square \square \square} \times \mathbf{1 0 0 \%}
$$

Keterangan rumus mencari nilai presentase dari jawaban kuesioner dapat dilihat pada tabel berikut:

Tabel 2. Keterangan Rumus Mencari

Nilai Persentase Kuesioner

\begin{tabular}{|c|c|}
\hline Nama & Keterangan \\
\hline $\mathrm{P}$ & Nilai Persentase yang Dicari \\
\hline $\mathrm{S}$ & $\begin{array}{c}\text { Jumlah frekuensi dikalikan skor } \\
\text { yang ditetapkan jawaban }\end{array}$ \\
\hline Skor Ideal & $\begin{array}{c}\text { Nilai tertinggi dikalikan dengan } \\
\text { jumlah sample }\end{array}$ \\
\hline $\begin{array}{c}\text { Nilai } \\
\text { Tertinggi } \\
\text { Sample }\end{array}$ & 5 \\
\hline $\begin{array}{c}\text { Nilai Skor } \\
\text { Ideal }\end{array}$ & $5 \times 30=150$ \\
\hline
\end{tabular}

Berikut ini adalah hasil pengumpulan data berupa jawaban dari masing-masing responden, dapat dilihat pada gambar berikut:

\begin{tabular}{|c|c|c|c|c|c|c|c|}
\hline \multirow{2}{*}{ No. } & \multirow{2}{*}{ Pernyataan } & & & & & & \multirow{2}{*}{ Total } \\
\hline & & SS & $\mathrm{S}$ & $\mathrm{N}$ & TS & STS & \\
\hline 1. & $\begin{array}{l}\text { Aplikasi virtual tour } \\
\text { sudah. } \\
\text { memperlihatkan } \\
\text { kondisi } \quad \text { gedung } \\
\text { Teaching Factory } \\
\text { seperti. keadaan } \\
\text { sesung }\end{array}$ & 12 & 15 & 3 & 0 & 0 & 30 \\
\hline 2. & $\begin{array}{l}\text { Aplikasi virtual tow } \\
\text { mudah digunalcan. }\end{array}$ & 4 & 14 & 12 & 0 & 0 & 30 \\
\hline 3. & $\begin{array}{l}\text { Menu aplikasi virtual } \\
\text { towr mudah } \\
\text { dipahami, }\end{array}$ & 10 & 16 & 4 & 0 & 0 & 30 \\
\hline 4. & $\begin{array}{l}\text { Informasi yang } \\
\text { ditampilkan aplikassit } \\
\text { virtual tour jelas. }\end{array}$ & 10 & 18 & 2 & 0 & 0 & 30 \\
\hline 5. & $\begin{array}{l}\text { Saya puas } \\
\text { menggunalcan } \\
\text { aplikasi, virtual tour } \\
\text { gedung Teaching } \\
\text { Factory Rolitelenits } \\
\text { Negeri Batam. }\end{array}$ & 10 & 18 & 3 & 0 & 0 & 30 \\
\hline
\end{tabular}

Gambar 10. Statistik Jawaban Responden 
Dari hasil pengumpulan data kuisioner dapat dilakukan penghitungan persentase untuk setiap pernyataan yang diberikan, adapun penjabarannya sebagai berikut:

1. Aplikasi virtual tour sudah memperlihatkan kondisi gedung Teaching Factory seperti keadaan sesungguhnya.

Tabel 3. Statistik Jawaban Responden Poin Kuesioner Nomor 1

\begin{tabular}{|c|c|c|c|}
\hline Keterangan & Skor & Responden & $\begin{array}{c}\text { Jumlah } \\
\text { Skor }\end{array}$ \\
\hline $\begin{array}{c}\text { Sangat } \\
\text { setuju }\end{array}$ & 5 & 12 & 60 \\
\hline Setuju & 4 & 15 & 60 \\
\hline Netral & 3 & 3 & 9 \\
\hline Tidak setuju & 2 & 0 & 0 \\
\hline $\begin{array}{c}\text { Sangat tidak } \\
\text { setuju }\end{array}$ & 1 & 0 & 0 \\
\hline Jumlah & & $\mathbf{3 0}$ & $\mathbf{1 2 9}$ \\
\hline
\end{tabular}

$$
P=\frac{129}{150} \times 100 \%=86 \%
$$

Berdasarkan nilai yang didapatkan maka dapat disimpulkan bahwa $86 \%$ dari 30 responden setuju bahwa aplikasi virtual tur sudah memperlihatkan kondisi gedung Teaching Factory seperti keadaan sesungguhnya.

2. Aplikasi virtual tour mudah digunakan.

Tabel 4. Statistik Jawaban Responden Poin Kuesioner Nomor 2

\begin{tabular}{|c|c|c|c|}
\hline Keterangan & Skor & Responden & $\begin{array}{c}\text { Jumlah } \\
\text { Skor }\end{array}$ \\
\hline $\begin{array}{c}\text { Sangat } \\
\text { setuju }\end{array}$ & 5 & 4 & 20 \\
\hline Setuju & 4 & 14 & 56 \\
\hline Netral & 3 & 12 & 36 \\
\hline Tidak setuju & 2 & 0 & 0 \\
\hline $\begin{array}{c}\text { Sangat tidak } \\
\text { setuju }\end{array}$ & 1 & 0 & 0 \\
\hline Jumlah & & $\mathbf{3 0}$ & $\mathbf{1 1 2}$ \\
\hline
\end{tabular}

$$
P=\frac{112}{150} \times 100 \%=74,67 \%
$$

Berdasarkan nilai yang didapatkan maka dapat disimpulkan bahwa 74,67 \% dari 30 responden setuju bahwa Aplikasi virtual tour mudah digunakan.

3. Menu aplikasi virtual tour mudah dipahami.

Tabel 5. Statistik Jawaban Responden Poin Kuesioner Nomor 3

\begin{tabular}{|c|c|c|c|}
\hline Keterangan & Skor & Responden & $\begin{array}{c}\text { Jumlah } \\
\text { Skor }\end{array}$ \\
\hline $\begin{array}{c}\text { Sangat } \\
\text { setuju }\end{array}$ & 5 & 10 & 50 \\
\hline Setuju & 4 & 16 & 64 \\
\hline Netral & 3 & 4 & 12 \\
\hline Tidak setuju & 2 & 0 & 0 \\
\hline $\begin{array}{c}\text { Sangat tidak } \\
\text { setuju }\end{array}$ & 1 & 0 & 0 \\
\hline Jumlah & 26 & $\mathbf{3 0}$ & $\mathbf{1 2 6}$ \\
\hline
\end{tabular}

Berdasarkan nilai yang didapatkan maka dapat disimpulkan bahwa $84 \%$ dari 30 responden setuju bahwa menu aplikasi virtual tour mudah.

4. Informasi yang ditampilkan aplikasi virtual tour jelas.

Tabel 6. Statistik Jawaban Responden Poin Kuesioner Nomor 4

\begin{tabular}{|c|c|c|c|}
\hline Keterangan & Skor & Responden & $\begin{array}{c}\text { Jumlah } \\
\text { Skor }\end{array}$ \\
\hline $\begin{array}{c}\text { Sangat } \\
\text { setuju }\end{array}$ & 5 & 10 & 50 \\
\hline Setuju & 4 & 18 & 72 \\
\hline Netral & 3 & 2 & 6 \\
\hline Tidak setuju & 2 & 0 & 0 \\
\hline $\begin{array}{c}\text { Sangat tidak } \\
\text { setuju }\end{array}$ & 1 & 0 & 0 \\
\hline Jumlah & & $\mathbf{3 0}$ & $\mathbf{1 2 6}$ \\
\hline
\end{tabular}

$$
P=\frac{128}{150} \times 100 \%=85,33 \%
$$


Tabel 7. Statistik Jawaban Responden Poin Kuesioner Nomor 5

\begin{tabular}{|c|c|c|c|}
\hline Keterangan & Skor & Responden & $\begin{array}{c}\text { Jumlah } \\
\text { Skor }\end{array}$ \\
\hline $\begin{array}{c}\text { Sangat } \\
\text { setuju }\end{array}$ & 5 & 10 & 50 \\
\hline Setuju & 4 & 18 & 72 \\
\hline Netral & 3 & 3 & 9 \\
\hline $\begin{array}{c}\text { Tidak } \\
\text { setuju }\end{array}$ & 2 & 0 & 0 \\
\hline $\begin{array}{c}\text { Sangat } \\
\text { tidak } \\
\text { setuju }\end{array}$ & 1 & 0 & 0 \\
\hline Jumlah & & $\mathbf{3 0}$ & $\mathbf{1 3 1}$ \\
\hline
\end{tabular}

$$
P=\frac{131}{150} \times 100 \%=87,33 \%
$$

Berdasarkan nilai yang didapatkan maka dapat disimpulkan bahwa $87,33 \%$ dari 30 responden puas menggunakan aplikasi virtual tour gedung Teaching Factory Politeknik Negeri Batam.

Untuk mencari presentase dari masingmasing jawaban kuesioner digunakan rumus skala likert sehingga menghasilkan 5 nilai untuk masing-masing poin kuesioner yaitu $87,33 \%, 76 \% 85,33 \%, 86,66 \%$, dan $88,66 \%$ responden menyetujui setiap pilihan pernyataan yang diajukan pada kuesioner.

Berdasarkan hasil presentase yang didapatkan melalui perhitungan kuisioner setiap pernyataan, didapatkan penghitungan hasil secara keseluruhan dengan rumus sebagai berikut:

$\mathrm{PK}=\Sigma$ presentase pernyataan sample $/ \Sigma$ presentase keseluruhan

Dengan menggunakan rumus persentase

keseluruhan maka didapatkan perhitungan sebagai berikut:

$\mathrm{PK}=(87.3 \%+76 \%+85.3 \%+86.6 \%+$

$88.6 \%) / 500 \%$

$\mathrm{PK}=423.8 / 500 \%=84.76 \%$

Maka dapat disimpulkan bahwa hasil perhitungan kuisioner dari 30 responden menyatakan $84.76 \%$ menyetujui pernyataanpernyataan yang disampaikan pada kuisioner yang diberikan.

Hasil dari pengujian fungsionalitas terhadap aplikasi virtual tour gedung

Teaching Factory Politeknik Negeri Batam yang telah dilaksanakan menunjukan bahwa sistem fungsional aplikasi bisa berjalan dengan baik dan sesuai dengan perancangan.

Hasil dari pengujian beta yang dilakukan dengan metode kuesioner adalah bahwa produk virtual reality gedung Teaching Factory Politeknik Negeri Batam dapat menginformasikan keadaan dan lokasi dari gedung TF. Tujuan dari penelitian untuk memperkenalkan gedung Teaching Factory Polteknik Negeri Batam dapat tercapai lewat informasi yang dapat ditampilakan kepada pengguna di setiap ruangan yang berada di gedung Teaching Factory Politeknik Negeri Batam. Produk virtual tour gedung Teaching Factory juga dapat berguna sebagai aset laboratorium virtual reality yang dapat ditunjukkan kepada para pengunjung laboratorium virtual reality Politeknik Negeri Batam dari berbagai institusi perusahaan maupun pendidikan tinggi lainnya.

\section{H. Distribution}

Produk virtual tour gedung Teaching Factory Politeknik Negeri Batam disimpan pada komputer yang berada di laboratorium virtual reality yang saat ini berada di gedung utama lantai 6 ruang 602 Politeknik Negeri Batam sehingga dapat diakses oleh setiap pengunjung lab dalam hal ini mahasiswa, dosen maupun tamu Polibatam dari berbagai institusi.

\section{KESIMPULAN}

Setelah tahap perancangan, implementasi dan pembuatan produk virtual tour gedung Teaching Factory dapat selesai, maka diperoleh kesimpulan terhadap aplikasi virtual tour gedung Teaching Factory Politeknik Negeri Batam sebagai berikut:

1. Telah berhasil dikembangkan produk virtual tour gedung Teaching Factory Politeknik Negeri Batam.

2. Pengunjung laboratorium virtual reality Politeknik Negeri Batam dapat mengetahui gambaran gedung dan informasi dasar dari setiap ruangan yang berada di gedung Teaching Factory Politeknik Negeri Batam.

3. Produk virtual tour dapat menjadi aset bagi laboratorium virtual reality untuk dapat dipakai dan dikembangkan selanjutnya. 


\section{REFERENSI}

[1] FRANCISCO TIGRE MOURA. 2017. Telepresence: The Extraordinary Power of Virtual Reality [internet]. Tersedia pada: < https : $\quad / /$ musicstats.org/telepresenceextraordinary-power-virtual-reality/> [Diakses 16 Oktober 2020

[2] Devi Dwi Purwanto, Herman Thuan To Saurik, Jeremiah Irawan Hadikusuma, Teknologi Virtual Reality untuk Media Informasi Kampus, 2019, Jurnal Teknologi Informasi dan Ilmu Komputer, (6), 71-76.

[3] Ichsan Syah Putra, (2018), Virtual Tour Sebagai Media Promosi Pariwisata Bahari Kota Batam, Tugas Akhir, Politeknik Negeri Batam.

[4] Devi Dwi Purwanto, Herman Thuan To Saurik, Jeremiah Irawan Hadikusuma, Teknologi Virtual Reality untuk Media Informasi Kampus, 2019, Jurnal Teknologi Informasi dan Ilmu Komputer, (6), 71-76.

[5] Hendro Trieddiantoro Puto 2015. Kajian Virtual Reality, Makalah Studi Mandiri: Universitas Teknologi Yogyakarta, Januari 2015.

[6] Andika, Dwiky, 2015. Pengertian Virtual Reality. https://www.it-jurnal.com. Diakses pada tanggal 10 Mei 2020.

[7] Nata, Gusti Ngurah Mega., 2017, Aplikasi Virtual Tour Guide Sebagai Promosi Pariwisata Bali, Jurnal Sistem Informatika., 11, 2, 73-79.

[8] Anonim, 2018, https://www.polibatam.ac.id/teachingfactory-polibatam/, diakses 02 Desember 2019 pukul 16.20.

[9] Creighton, R. 2010. Unity 3D Game Development by Example Begginer's Guide. Packt Publishing Ltd.32 Lincoln Road 32 :
Birmingham, B27 6PA, UK.

[10] Andrade, A. 2013. Robotic Arm Control With Blender. Journal of Emerging Trends in Computing and Information Sciences, 4(4) 382-386.

[11] Moleong, L. 2013. Implementasi Cluster Computing Untuk Render Animasi. EJurnal Tenik Elektro dan Komputer Universitas Sam Ratulangi Manado.

[12] Luther, A. C., 1994, Authoring Interactive Multimedia, Academic Press,

Inc., Massachusettes.

[13] Iwan Binanto, Tinjauan Metode Pengembangan Perangkat Lunak Multimedia yang Sesuai untuk Mahasiswa Tingkat Akhir, 2015, Seminar Nasional Rekayasa Komputer dan Aplikasinya, 148-155.

[14] Aditya Fernando, Akip Suhendar, 2016, Aplikasi Virtual Tour Berbasis Multimedia Interaktif Menggunakan Autodesk 3Ds Maks, Jurnal ProTekInfo (3), 30-35.

[15] Willy Ahmad Syafiq, (2015), Pembangunan Aplikasi Panduan Layanan Pengunjung Berbasis Virtual Reality Di Rumah Sakit Mata Cicendo Bandung, Skripsi, Digital Library Unikom. 